\title{
CALCULATION OF INTERMEDIATE SUPPORTING PARTS OF INSEPARABLE PERFORATED BEAMS IN THE SOFTWARE COMPLEX «LIRA»
}

\author{
Romaniuk V.V., Ph.D., Assistant Professor, \\ ORCID:0000-0002-2539-4654 \\ Supruniuk V.V., Ph.D., Assistant Professor, \\ ORCID:0000-0001-9534-4460 \\ Bezniuk L.I., postgraduate student, \\ ORCID: 0000-0001-6703-5062 \\ National University of Water and Environmental Engineering (Rivne)
}

\begin{abstract}
Due to the simplicity of design and manufacture, as well as reliability during operation, beams are one of the most common elements used in industrial, civil and public construction. The most rational cross-section of metal beams are rolled I-beams with inclined or parallel inner faces of the shelves, the predominant use of which is due to the value of the core distance, which is twice as much the same value for a rectangular section and almost three times for a round section. This figure is even higher for perforated profiles obtained from conventional rolling beams, which allow you to compose sections with increased values of moments of inertia and moments of resistance without increasing material consumptions. For inseparable beams, an additional significant factor influencing on their bearing capacity, is the structural design of the intermediate support part.

The aim of these researches is to study the stress-strain state of inseparable perforated beams of I-beam profile of different heights in areas near the intermediate support, the design of which is made without a transverse stiffening rib placed on the axis of the support, and with unwelded holes to the left and right of the support under the action of evenly distributed load in the software complex "Lira". The objectives of the study are to establish the actual values of stresses and strains in the characteristic cross sections of the inseparable perforated I-beam, which occur on the intermediate support, and perform a comparative analysis of numerical studies obtained in the software complex "Lira" for intermediate support node beams of different heights for actions of different magnitudes of loads. The analysis of the obtained diagrams of normal stresses was carried out, which showed that for the proposed design of the support part of the beam, the cross-sections with holes directly to the left and right of the support are calculated. The conclusion about necessity of carrying out further experimental-theoretical researches of various types of support parts of beams for the purpose of development of a complex technique of their calculation and recommendations on definition of rational scope of application of each of them is formulated.
\end{abstract}

Key words: inseparable beam, intermediate support, section, perforation, stress, deformation, bearing capacity, software complex.

Introduction. Due to the simplicity of design and manufacture, as well as reliability during operation, beams are one of the most common elements used in industrial, civil and public construction to cover spans up to $18 \ldots 20 \mathrm{~m}$ and even more. Their work on transverse bending, as a result of which the bending moment and transverse force occur along the length of the element, and normal and tangential stresses develop in the cross section, is possible due to the presence in their design of horizontal elements (shelves or belts), which give the beam the necessary rigidity, and a vertical wall connecting the belts, and provides shear resistance to the action of transverse forces. Beams are statically significant (single-span split and cantilever) and statically indeterminate (multispan inseparable, multi-span with consoles and clamped). Inseparable beams have lower metal consumptions and they have smaller deflections in the span under the action of any type of load. 
The most rational cross-section of metal beams, given the ease of manufacture, cost and compliance with the resulting stress are rolled I-beams with inclined or parallel inner faces of the shelves. The predominant use of such a profile is due to the value of the core distance $\rho=W / A$, which is twice as much the same value for a rectangular section and almost three times for a round section. This figure is even higher for perforated profiles obtained from conventional rolling beams, which allow you to compose sections with increased values of moments of inertia and moments of resistance without increasing material consumptions. The cross-section in which the material is concentrated at a certain distance from the horizontal axis, ie in the shelves, best corresponds to the nature of the distribution of normal and tangential stresses arising from the bending of the beams. For inseparable beams, a significant factor influencing on their bearing capacity, in addition to the magnitude, nature of action (static or dynamic), type (concentrated, evenly distributed, combined), load action patterns; strength of the material (steel of normal strength or high strength); span values of a beam; geometrical parameters of cross section, there is a construction of an intermediate support part of a beam.

Analysis of existing researches. The current design standards for steel structures [1] briefly present the general principles of design of perforated beams, the formulas for calculating normal stresses at characteristic points of cross section with a hole are given in them and they emphasize the need to strengthen the cross section on the support by transverse stiffeners. In other matters, perforated beams are subject to the same requirements as conventional rolling beams according to [2, $3]$. This refers only to single-span beams, and the design features of multi-span inseparable perforated beams are not considered at all. European design standard for steel structures [4] do not currently regulate the calculation of perforated elements.

There are numerous experimental and theoretical studies of bending perforated elements, performed by both domestic and foreign scientists, but they do not answer all the questions related to the features of the calculation and design of multi-span inseparable beams.

During the studies of the bearing capacity of the prestressed arch, the results of which are presented in $[5,7,8]$, were clarified certain features of the work and the stress-strain state of the upper belt of the arch made of perforated I-beam, which worked on an inseparable scheme, because it had an intermediate support in the form of a pre-stressed stud. The obtained information prompted the authors to consider the need for additional comprehensive experimental and theoretical studies of the area of the bending element near the intermediate support. At the first stage, it is advisable to use the software complex "Lira", which is widely used in the practice of designing various building structures and which has confirmed its high efficiency and accuracy in the study of perforated beams Z-shaped profile [6].

The purpose of researches. The aim of this work is to study the stress-strain state of inseparable perforated beams of I-beam profile of different heights obtained from the original I-beams №№ 20, 30, 40, 50 and 60 (GOST 8239-89) of steel class C235 with the coefficient of development of cross section $k=1,5$ in areas near the intermediate support, the design of which is made without a transverse stiffener placed on the axis of the support, and with unwelded holes to the left and right of the support under the action of evenly distributed load in the software complex "Lira". The objectives of the study are to establish the actual values of stresses and strains in the characteristic cross sections of the inseparable perforated I-beam, which occur on the intermediate support, and perform a comparative analysis of numerical studies obtained in the software complex "Lira" for intermediate support node beams of different heights and different in value loads for the specified variant of its constructive design.

Research methods. Analysis of literature sources devoted to theoretical and experimental studies of perforated structures, as well as the use of the finite element method, implemented in the software complex "Lira".

Presenting main material. Modeling of perforated inseparable beam (Fig. 1) of I-beam section (Fig. 2) was performed in the software complex "Lira" based on the finite element method, the essence of which is that any continuous quantity can be approximated by a piecewise continuous function under construction in real sizes with all design features, in a finite number of points. 


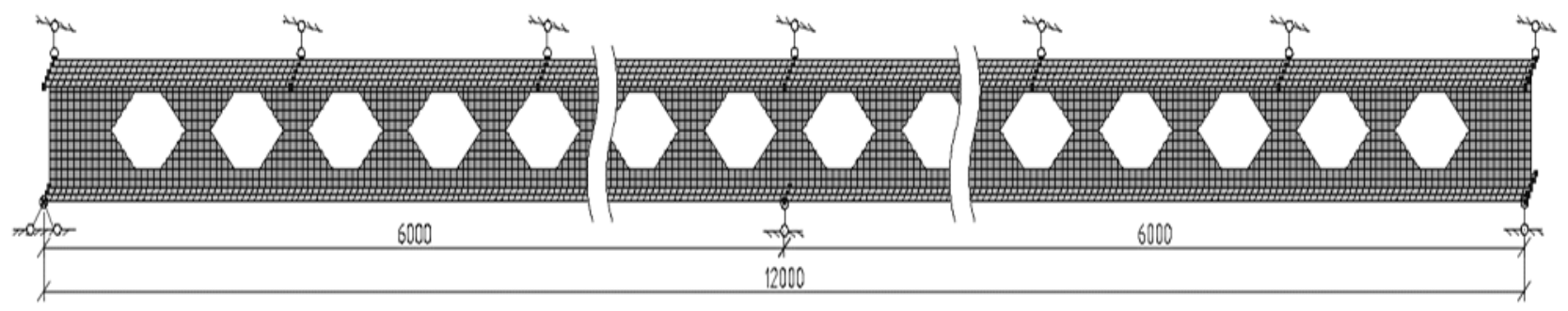

Fig. 1. Model of inseparable perforated beam in the SC "Lira"

To build a discrete model of a continuous value of perforated beams with hexagonal holes, the following conditions are accepted:

1) the region of the quantity under study is divided into a finite number of elements that have common nodal points that generally approximate the shape of the region;

2) nodes in the area under consideration are fixed;

3) the values in the middle of the region are determined at the nodal points, which approximate the function, using the values of the continuous quantity under study.

From the point of view of construction of an inseparable perforated beam it is considered as set of constructive elements (walls and shelves) which are connected among themselves in nodal points. If you know the relationship between forces and displacements for each element, you can describe the properties and investigate the behavior of the structure as a whole.

The beam was divided by a grid of finite elements, based on the following conditions $a \geq 2 t$ and $b \geq 2 t$, where $a$ and $b$ - are the length and width of the finite elements; $t$-is the thickness of the elements (shelves, walls) under consideration. Finite elements of the shelf and the wall are square in shape with the dimensions presented in table 1. Finite elements near hexagonal holes are formed by three- and four-node plates. The angle of inclination of the inclined face of the hole $\alpha=45^{\circ}$. The accepted sizes and the form of finite elements allow to receive high accuracy of calculation.

Fastening of the ends of the perforated two-span beam with the same spans $l=6 \mathrm{~m}$ is accepted: the extreme support on the left is articulated; the extreme support on the right is hinged; intermediate support - hinged. To fasten the beam from the plane of action of the load used transverse elements, which are placed on the upper belts of the profile with a step of $1 \mathrm{~m}$ (see Fig. 1). This made it possible to eliminate transverse deformations of the modeled structure and bring its operation as close as possible to the work of the real structure.

The following variants of a design of an intermediate support part of an inseparable perforated beam are possible:

1) without a stiffening rib placed on the axis of the intermediate support, and with unwelded holes to the left and right of the support (Fig. 3) (type 1);

2) with a stiffening rib placed on the axis of the intermediate support, and with unwelded holes to the left and right of the support (type 2);

3) without a stiffening rib placed on the axis of the intermediate support, and with welded holes to the left and right of the support (type 3);

4) with a stiffening rib placed on the axis of the intermediate support, and with welded holes to the left and right of the support (type 4).

In this article, we consider the stress-strain state of only the support type 1 (see Fig. 3).

The composition of the intermediate support part of the beam includes two sections with a length of $l_{1}=700 \ldots 1800 \mathrm{~mm}$ to the left and right of the axis of the support. Thus, the length of the support part depending on the height of the perforated beam $h=300 \ldots 900 \mathrm{~mm}$ and is $2 l_{1}=$ $1400 \ldots 3600 \mathrm{~mm}$ (see Fig. 3). The size $l_{1}-$ is the distance from the point of intersection of the diagram of the bending moment $M$ of the neutral line, ie the zero point, to the axis of the intermediate support. 


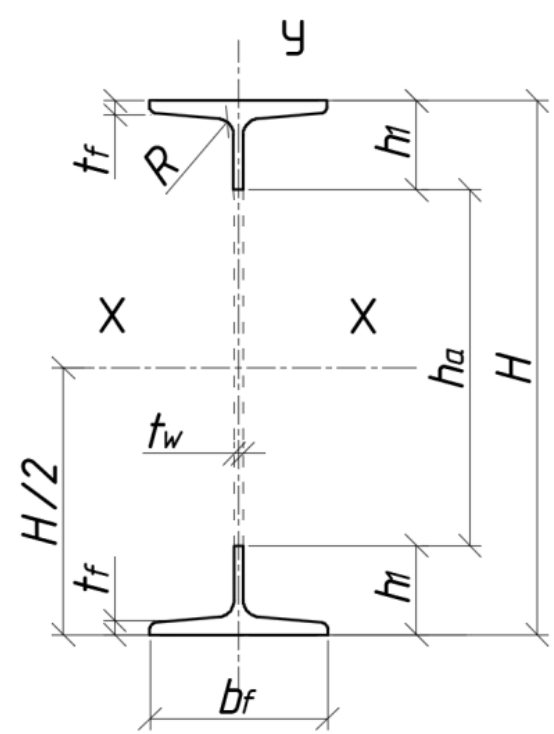

Fig. 2. Cross section of the perforated beam

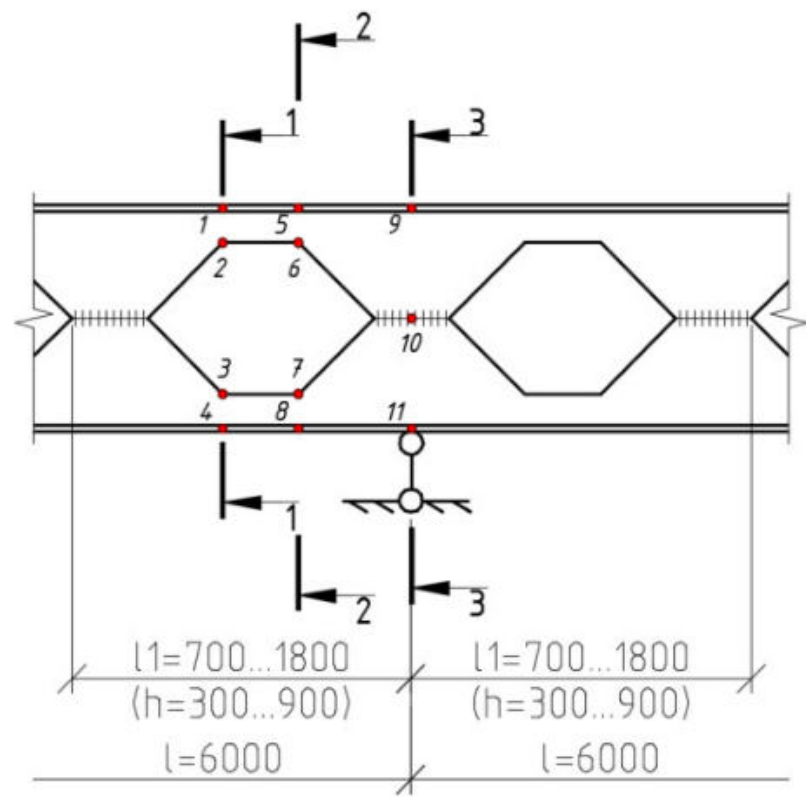

Fig. 3. Support section without stiffeners and with unwelded holes (type 1)

Using the known formulas for determining the values of transverse forces and bending moments at characteristic points and cross sections along the length of a two-span continuous beam under the action of a certain uniformly distributed load, we can determine the amount of load for which the beam will have a limit state, belonging to the limit states of the 1st group, namely the loss of bearing capacity because of achieving in the cross section of the beam of the limit normal stresses. Based on these considerations, the limit values of the calculated uniformly distributed load $q$ for beams of different heights are calculated. And these loads are calculated for the original I-beams №№ 20, 30, $40,50,60$ and are respectively $q=16,45 ; 45,22 ; 85,24 ; 142,1 ; 229,0 \mathrm{kN} / \mathrm{m}$. The notation of the geometric parameters of the beams is presented in Fig. 4, and their numerical values are given in table 1.
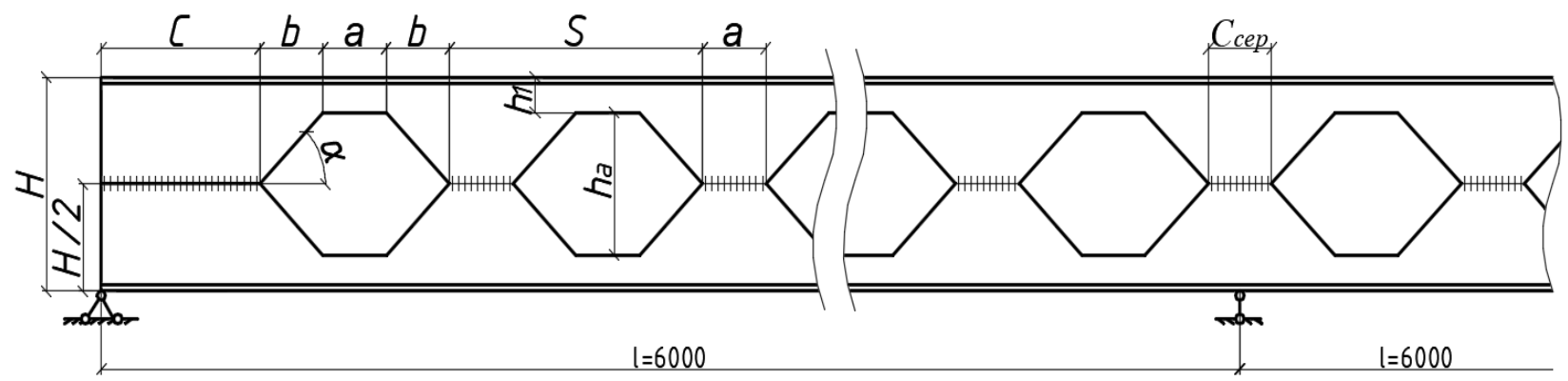

Fig. 4. Symbols of geometrical parameters of inseparable perforated beams

Research results. Analysis of the diagrams of the stresses given in table 2 , indicates a significant change in the stress-strain state of the calculated cross sections as you approach from the middle of the span of the beam to the axis of the intermediate support. In the middle part of the beam, the stress distribution in the section with the hole is traditional - stresses at the points of the upper brand of cross section have a sign "minus", and at the points of the lower brand - sign "plus" in full accordance with the diagrams of bending moment.

In the calculated cross-sections of the support part of the beam 1-1 and 2-2 (see Fig. 3) the stress distribution is completely different and it differs not only from the stresses in the span, but also has significant differences in these sections, although the distance between them is quite insignificant and is depending on the height of the beam $a=100 \ldots 300 \mathrm{~mm}$. 
$\frac{-}{\frac{0}{0}}$

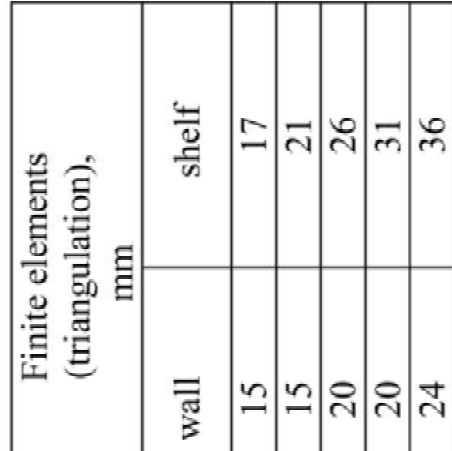

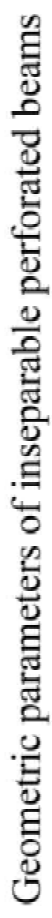

\section{亡}

น

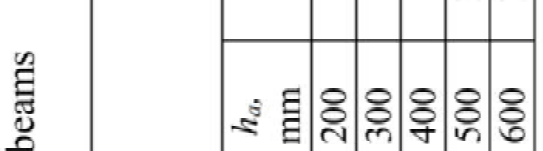

•

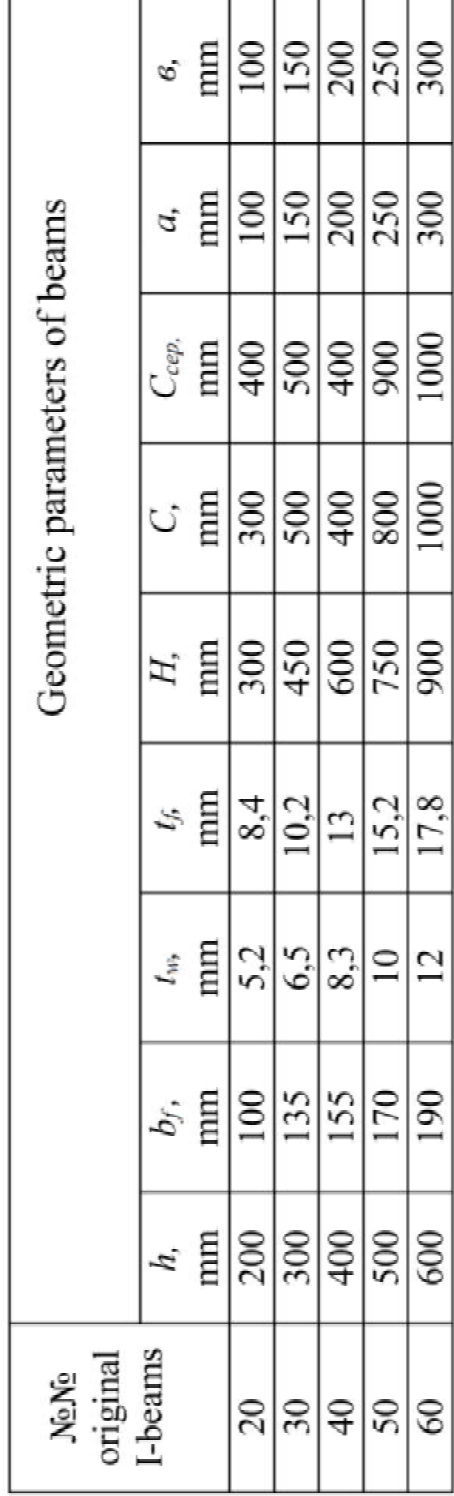

U
$\frac{0}{0}$
है

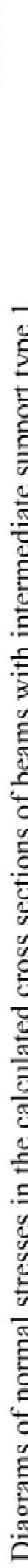

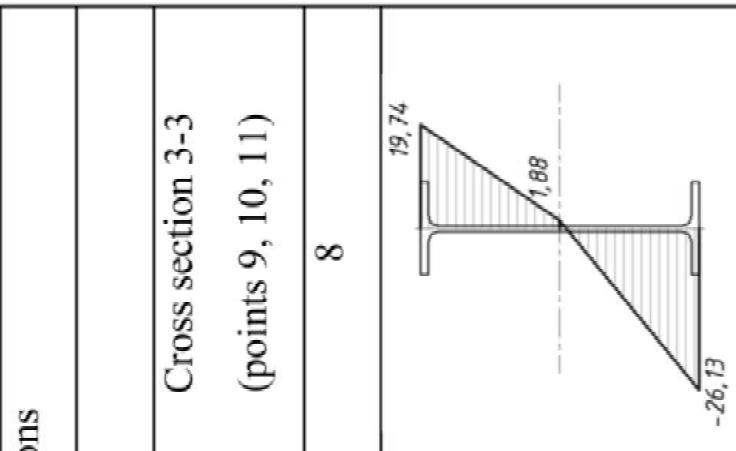

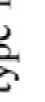

.

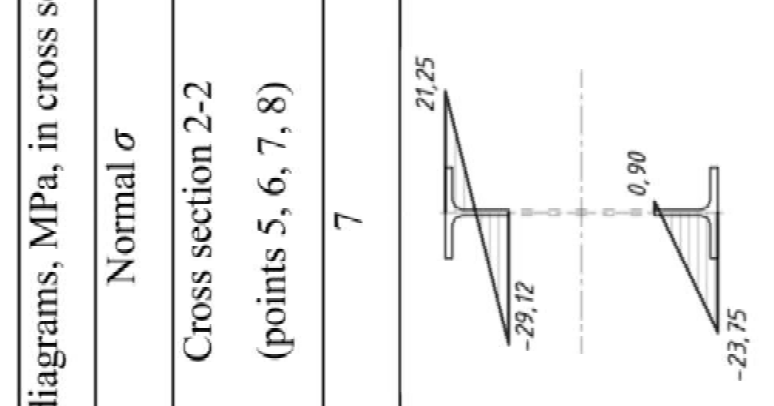




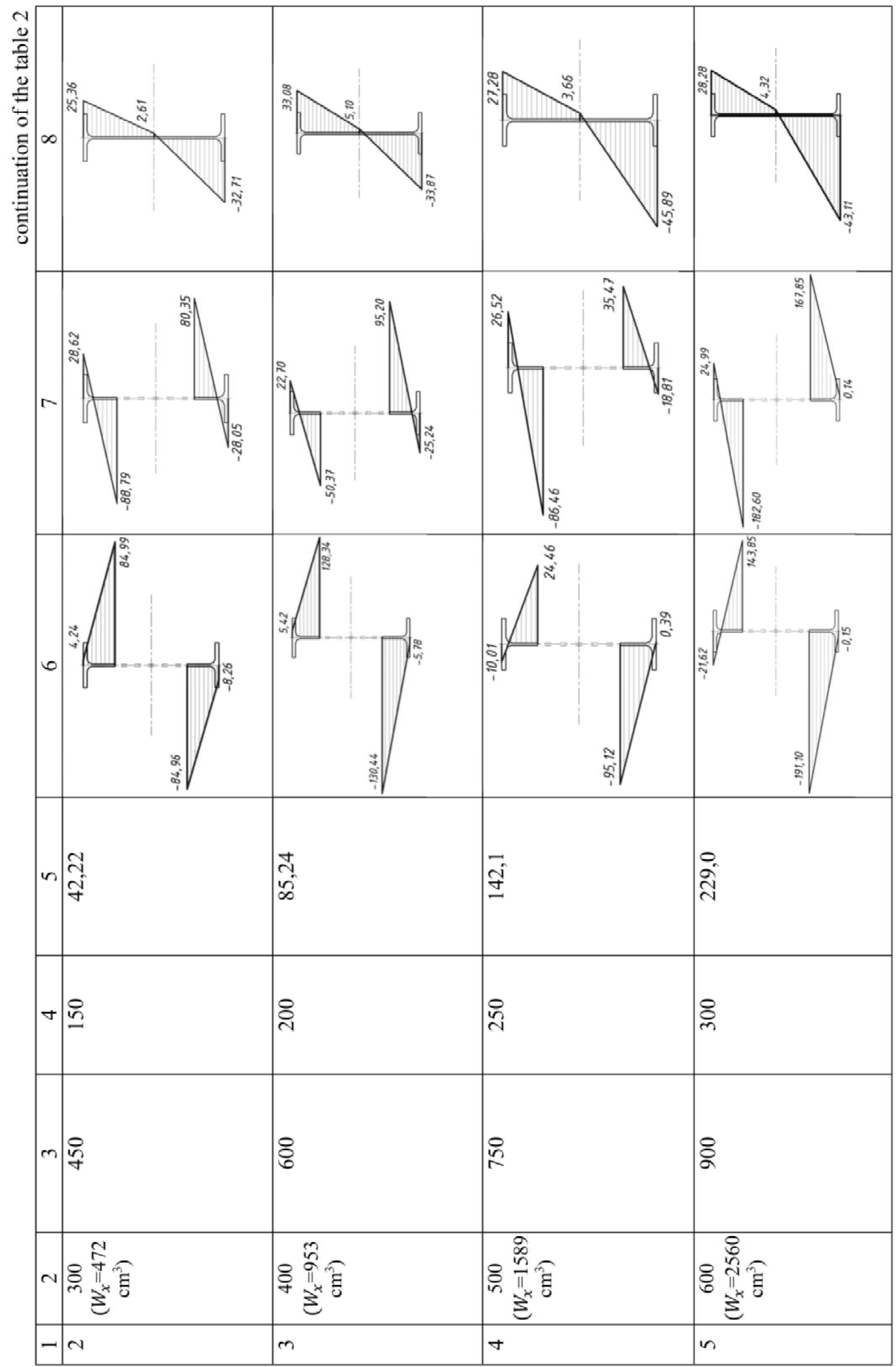


At first glance, this distribution of stresses in sections with holes is illogical, because at the calculation points located in the stretched zone of the beam (points 2 and 6) the sign of stresses changes from "plus" to "minus ", and points of the compressed zone of the beam (point 3 and 7) from "minus" to "plus" (see Table 2). Moreover, this pattern is preserved for beams of any height under the action of any magnitude of the load.

Why this happens becomes clear after careful study and analysis of the isofields of normal stresses in the supporting part of the beam (Fig. 5). Due to the presence of perforation holes along the length of the support part and the local influence of the reaction of the intermediate support in the wall of the beam there are local stress zones, the sign of which does not coincide with the general sign of stresses. Thus, in the upper part of the beam, which is generally stretched, around point 6 of section 2-2 in the beams of all heights there is a local area of compression stresses of different magnitudes. Its presence, in our opinion, can be explained by the local influence of the reaction of the intermediate support. Conversely, around point 7, which is located in the compressed zone of the beam, there is a local area of tensile stresses, the presence of which can be explained by a significant uneven deformation around the hole, ie the presence of these holes themselves.

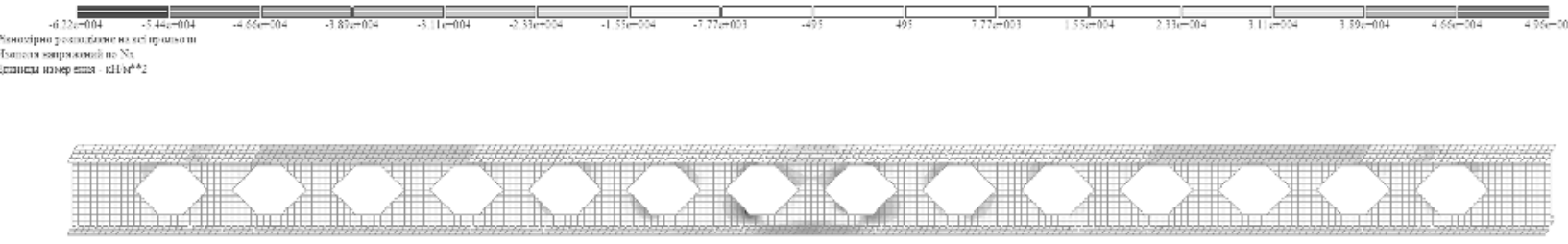

Fig. 5. Isofields of normal stresses in an inseparable two-span perforated beam

For all beams, regardless of their height and the magnitude of the applied load, the greatest tensile or compressive stresses occur at the calculation points 2 and 3 in section $1-1$ and at points 6 and 7 in section 2-2. For beams of all heights presented in table 2, the stresses at these calculation points do not exceed the calculated resistance of steel class C235 $R_{y}=230 \mathrm{MPa}$, which is accepted to be the same in the calculation of all beams. Therefore, there is no need to weld holes to the left and right of the intermediate support. The stresses in the continuous section 3-3 along the axis of the intermediate support are much smaller. To ensure the local stability of the wall, you can use a pair of transverse stiffeners placed on the axis of the support. Then in the calculation of the supporting part of the beam, these ribs are included in its composition and due to the increase of the geometric parameters of the cross section stresses decrease.

Summary. The stress distribution at the calculated points of the characteristic sections with holes of the iseparable perforated beam near the intermediate support differs significantly from the stress distribution in the calculated sections of the span part, because the sign of the diagram of the bending moment in the support part changes from positive to negative and this completely changes the nature of the stress-strain state. This change indicates the impossibility of using the formulas of current design standards [1] to calculate stresses at calculation points, which confirms the need for further experimental-theoretical studies of different types of support parts of beams to develop a comprehensive method for their calculation and recommendations for determining the rational scope of each of them.

\section{References}

[1] DBN V.2.6-198:2014. Stalevi konstruktsiyi. Normy proektuvannya [Chynnyy vid 2015-01-01]. Kyyiv :Minrehion Ukrayiny, 2014. 198 s. (Derzhavni budivel'ni normy Ukrayiny).

[2] DBN V.1.2-2:2006. Systema zabezpechennya nadiynosti ta bezpeky budivel'nykh ob yektiv. Navantazhennya i vplyvy. Normy proektuvannya [Na zaminuSNyP 2.01.07-85; chynnyy vid 2007-10-01]. Kyyiv :Minrehion Ukrayiny, 2006. 75 s. (Derzhavni budivel'ni normy Ukrayiny).

[3] DSTU B V.1.2-3:2006. Systema zabezpechennya nadiynosti ta bezpeky budivel'nykh ob 'yektiv. Prohyny i peremishchennya. Vymohy proektuvannya [Na zaminu rozdilu10 SNyP 
2.01.07-85; chynnyy vid 2007-01-01]. Kyyiv :Minbud Ukrayiny, 2006. 10 s. (Natsional'ny ystandart Ukrayiny).

[4] Eurocode 3: Design of steel structures. EN 1993-1-8:2005.

[5] Romaniuk V. V., Supruniuk V. V. Mitsnist' ta deformatyvnist' perforovanykh elementiv stalevoyi arky (Strength and deformability of perforated elements of steel arch): monohrafiya. Rivne: NUVHP, 2013. $106 \mathrm{s.}$

[6] Romaniuk V. V., Vasylenko V. B., Supruniuk V. V. Nesucha zdatnist' perforovanykh prohoniv Z-podibnoho profilyu za kosoho zhynu (Carrying capacity of perforated runs of Zshaped profile in oblique bending) : monohrafiya. Rivne: NUVHP, 2017. 206 s.

[7] Romaniuk V. V., Supruniuk V. V. Osoblyvosti rozrakhunku prol'otnykh konstruktsiy z perforovanykh elementiv za skladnoho napruzheno-deformovanoho stanu (Features of the calculation of span structures from perforated elements in complex stress-strain state). Zbirnyknaukovykhprats' Ukrayins'koho derzhavnoho universytetu zaliznychnoho transportu. Kharkiv: UkrDUZT, 2018. Vypusk 175.S. 98 - 108.

[8] Romaniuk V.V., Supruniuk V. V. Eksperymental'ni doslidzhennya prol'otnykh konstruktsiy z perforovanykh elementiv za skladnoho napruzheno-deformovanoho stanu (Experimental researches of flexible constructions from perforated elements at a complex stress-deformed state). Opir materiali i teoriya sporud: nauk. -tekh.zbirn. K.: KNUBA, 2019. Vyp. 103. S. 189200.

\section{РОЗРАХУНОК ПРОМІЖНИХ ОПОРНИХ ЧАСТИН НЕРОЗРІЗНИХ ПЕРФОРОВАНИХ БАЛОК У ПРОГРАМНОМУ КОМПЛЕКСІ «ЛІРА»}

Романюк В.В., к.т.н., доцент, ORCID:0000-0002-2539-4654

Супрунюк В.В., к.т.н., доцент, ORCID:0000-0001-9534-4460

Безнюк Л.І., аспірант, ORCID: 0000-0001-6703-5062 Національний університет водного господарства та природокористування (м. Рівне)

Анотація. Завдяки простоті конструктивної форми та виготовлення, а також надійності під час експлуатації балки $\epsilon$ одними 3 найбільш розповсюджених елементів, які застосовуються у промисловому, цивільному i громадському будівництві. Найбільш раціональним перерізом металевих балок є прокатні двотаври з похилими або паралельними внутрішніми гранями полиць, переважне використання яких зумовлене значенням ядрової відстані, яке удвічі перевищує аналогічне значення для прямокутного перерізу і майже утричі для круглого. Цей показник $є$ ще більшим для перфорованих профілів, отриманих зі звичайних прокатних балок, які дозволяють компонувати перерізи зі збільшеними значеннями моментів інерції і моментів опору без збільшення витрат матеріалу. Для нерозрізних балок додатковим суттєвим фактором, що впливає на їх несучу здатність, $є$ конструктивне оформлення проміжної опорної частини.

Метою проведених досліджень $є$ вивчення напружено-деформованого стану нерозрізних перфорованих балок двотаврового профілю різної висоти на ділянках біля проміжної опори, конструкція якої виконана без поперечного ребра жорсткості, розміщеного по осі опори, і 3 незавареними отворами зліва і справа від опори за дії рівномірно розподіленого навантаження у програмному комплексі «Ліра». Завданнями дослідження $\epsilon$ встановлення фактичних значень напружень i деформацій у характерних перерізах нерозрізної перфорованої балки двотаврового профілю, які виникають на проміжній опорі, та виконання порівняльного аналізу результатів числових досліджень, отриманих у програмному комплексі „Ліра”, для проміжного опорного вузла балок різної висоти і за дії різних за величиною навантажень. Проведено аналіз отриманих епюр нормальних напружень, який засвідчив, що для 
запропонованої конструкції опорної частини балки розрахунковими є перерізи з отворами безпосередньо зліва і справа від опори. Зроблено висновок про необхідність проведення подальших експериментально-теоретичних досліджень різних типів опорних частин балок 3 метою розробки комплексної методики їх розрахунку та рекомендацій щодо визначення раціональної області застосування кожного з них.

Ключові слова: нерозрізна балка, проміжна опора, переріз, перфорація, напруження, деформація, несуча здатність, програмний комплекс.

\section{РАСЧЕТ ПРОМЕЖУТОЧНЫХ ОПОРНЫХ ЧАСТЕЙ НЕРАЗРЕЗНЫХ ПЕРФОРИРОВАННЫХ БАЛОК В ПРОГРАММНОМ КОМПЛЕКСЕ «ЛИРА» \\ Романюк В.В., к.т.н., доцент, ORCID:0000-0002-2539-4654}

Супрунюк В.В., к.т.н., доцент, ORCID:0000-0001-9534-4460

Безнюк Л.I., аспирант, ORCID: 0000-0001-6703-5062 Национальный университет водного хозяйства и природопользования (2. Ровно)

Аннотация. Благодаря простоте конструктивной формы и изготовления, а также надежности во время експлуатации балки являются одними из наиболее распространенных элементов, используемых в промышленном, гражданском и общественном строительстве. Наиболее рациональным сечением металлических балок являются прокатные двутавры 3 наклонными или параллельными внутренними гранями полок, преимущественное применение которых обусловлено значением ядрового расстояния, которое в два раза превышает аналогичное значение для прямоугольного сечения и почти в три для круглого. Этот показатель еще больше для перфорированных профилей, полученных из обычных прокатных балок, которые позволяют компоновать сечения с большими значениями моментов инерции и моментов сопротивления без увеличения затрат материала. Для неразрезных балок дополнительным существенным фактором, влияющим на их несущую способность, является конструктивное оформление промежуточной опорной части. Цель проведенных исследований состоит в изучении напряженно-деформированного состояния неразрезных перфорированных балок двутаврового профиля разной высоты на участках вблизи промежуточной опоры, конструкция которой выполнена без поперечного ребра жесткости, расположенного по оси опоры, и с незаваренными отверстиями слева и справа от опоры, при действии равномерно распределенной нагрузки в программном комплексе «Лира». Задачами исследований являются определение фактических значений напряжений и деформаций в характерных сечениях неразрезной перфорированной балки двутаврового профиля, которые возникают на промежуточной опоре, и проведение сравнительного анализа результатов числовых исследований, полученных в программном комплексе «Лира», для промежуточного опорного узла балок разной высоты при действии разных по величине нагрузок. Выполнен анализ полученных эпюр нормальных напряжений, который показал, что для предложенной конструкции опорной части балки расчетными являются сечения с отверстиями непосредственно слева и справа от опоры. Сделан вывод о необходимости проведения дальнейших экспериментально-теоретических исследований разных типов опорных частей балок с целью разработки комплексной методики их расчета и рекомендаций по определению рациональной области использования каждого из них.

Ключевые слова: неразрезная балка; промежуточная опора, сечение, перфорация, напряжение, деформация, несущая способность, программный комплекс. 